\title{
PENINGKATAN KUALITAS PRODUK UMKM KAMPUNG WISATA BISNIS TEGAL WARU DALAM UPAYA KOMERSIALISASI PRODUK BERDAYA SAING DAN BERBASIS INFORMASI TEKNOLOGI
}

\author{
Endang Purwaningsih ${ }^{1)}$, Muslikh ${ }^{2)}$, Suhaeri $^{3)}$ \\ 1) Fakultas Hukum Universitas YARSI Jakarta Pusat \\ ${ }^{2)}$ Fakultas Ekonomi Universitas YARSI Jakarta Pusat \\ ${ }^{3)}$ Fakultas Teknik Informatika Universitas YARSI Jakarta Pusat \\ E-mail: e.purwaningsih@yarsi.ac.id
}

\begin{abstract}
Abstrak
Tujuan program ini adalah: 1) meningkatkan kualitas desain kemasan dan produk, 2) pelindungan hukum atas merek (branding) produk UMKM Kampung Wisata Tegal Waru Bogor, 3) perluasan jaringan pemasaran melalui internet (on-line), dan 4) meningkatkan kompetensi manajemen pemasaran, sehingga mampu meningkatkan omzet/daya saing produk. Metode pendekatan dengan mengadakan pelatihan dan pendampingan secara terus menerus sampai mandiri. Pelatihan dikemas secara praktis dengan mengambil tempat di tempat usaha yaitu Kampung Wisata Bisnis Tegal Waru Bogor.Solusi yang ditawarkan melalui antara lain dengan mengadakan: 1) pelatihan peningkatan kualitas desain kemasan dan produk, 2) pelatihan pembuatan dan pendaftaran merek produk, 3) pelatihan perluasan jaringan pemasaran melalui internet (online), dan 4) pelatihan manajemen pemasaran. Program tersebut telah dilaksanakan secara kontinue (terus menerus) sehingga dapat diketahui perkembangan mitra (UMKM) Kampung Wisata Tegal Waru dari waktu ke waktu. Hasil kegiatan ini dapat dijelaskan bahwa (1) Produsen Kampung Wisata Bisnis Tegalwaru perlu diberdayakan dari segala hal, baik status badan usaha, keberlanjutan produksi, dan membrandingya, (2) $e$ commerce belum dilakukan dengan baik, sebagian kecil dari mereka memanfaatkan media sosial pribadi, dan memerlukan link kerjasama berbagai pihak untuk membantu, Tim Abdimas telah membuatkan dan menyumbangkannya (3) belum tergerak untuk mendaftarkan merek, karena yang penting laku dan survive. Desain produk dan kemasannya masih seadanya, perlu didampingi dan dilatih. Telah dibuat model pemberdayaan UMKM Tegal Waru dan siap untuk diterapkan.
\end{abstract}

Kata Kunci : Desain, merek produk UMKM, pemasaran on-line, daya saing

\section{PENDAHULUAN}

Desa Tegal Waru yang kemudian dipopulerkan dengan Kampung Wisata Bisnis Tegal Waru berada di wilayah Kecamatan Ciampea Kabupaten Bogor, terletak di sebelah barat Kabupaten Bogor atau sekitar 3 KM dari kampus IPB Dramaga, dan dapat ditempuh dalam waktu 1 (satu) jam dari Jakarta. Dilihat dari monografi Desa Tegal Waru terdiri dari 38 RT, 6 RW, dan memiliki jumlah penduduk sebanyak 12.123 jiwa. Sebagian besar masyarakat berprofesi sebagai petani dan wirausaha, hanya saja pada setiap RW masyarakatnya memiliki spesifikasi usaha dan semua tergolong UMKM.

Berdasarkan hasil wawancara dengan Tatiek Kancaniati 2 April 2017 Ketua Yayasan Kuntum Indonesia diketahui empat permasalahan mendasar yang disarankan pada saat ini yaitu: 1) rendahnya kualitas desain kemasan \& produk, 2) merek produk belum terlindungi, 3) keterbatasan jangkauan pemasaran produk yang belum on-line, dan 4) kompetensi manajemen pemasaran yang masih rendah yang mengakibatkan daya saing produk yang dihasilkan masih rendah.

Agar Usaha UMKM tetap eksis dan kinerjanya meningkat dari waktu ke waktu, maka Universitas YARSI dengan multidisiplin dari Fakultas Hukum, Fakultas Ekonomi, Fakultas Teknologi Informasi sekaligus Sekolah Pascasarjana-- karena Tim juga mengajar di Sekolah Pascasarjana--memandang perlu untuk melakukan program pengabdian kepada masyarakat berupa pelatihan berbagai hal di atas bagi pemberdayaan UMKM di Kampung Wisata Bisnis Tegal Waru Bogor dalam bentuk pendampingan mulai dari: 1) pelatihan peningkatan kualitas desain produk dan kemasan, 2) pelatihan perlindungan hukum atas merek produk, 3) pelatihan perluasan jaringan pemasaran melalui internet (on-line), dan 4) pelatihan manajemen pemasaran. Program tersebut akan dilaksanakan secara kontinue (terus menerus) sehingga dapat diketahui perkembangan mitra (UMKM) Kampung Wisata Bisnis Tegal Waru dari waktu ke waktu. 
Dengan berbagai program pelatihan tersebut ditargetkan terjadi peningkatan wawasan, ilmu dan pengetahuan pada anggota UMKM. Selain itu, dengan program tersebut diharapkan terjalin silaturahim yang lebih intensif antara usaha mikro Kampung Wisata Bisnis Tegal Waru dengan 4 Fakultas di Universitas YARSI. Dengan komunikasi dan silaturahim yang baik, keberadaan dan keunggulan Universitas YARSI akan tersosialisasikan ke masyarakat.

\section{Permasalahan Mitra}

Permasalahan yang dihadapi usaha mikro Tegal Waru Bogor dan berbagai prioritas yang perlu dilakukan sebagaimana tampak pada tabel 1 .

Tabel 1. Analisis situasi permasalahan yang dihadapi usaha mikro Tegal Waru Bogor dan prioritas pendampingan

\begin{tabular}{|c|c|c|}
\hline No & Jenès pesmasalaham & 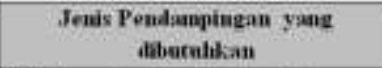 \\
\hline 1 & $\begin{array}{l}\text { Kurangnya kreativitan dan inovast } \\
\text { dalaen dessin kemasan dan produk }\end{array}$ & $\begin{array}{l}\text { Detatihan penitgkatan kualtra desais } \\
\text { kemasan dasn proctak }\end{array}$ \\
\hline 2 & $\begin{array}{l}\text { Belam adasya merek UMKKM yang } \\
\text { terdafar di Ditjen KI Kemenlam- } \\
\text { HAM }\end{array}$ & $\begin{array}{l}\text { Pelatihan pembuatan merek dan pendaftaran } \\
\text { ke Ditjen KI Komerekum-HAM }\end{array}$ \\
\hline 3 & $\begin{array}{l}\text { Blotum adanya isovasi pertuasan } \\
\text { jaringan pemasaran melalui internet } \\
\text { (an-line) }\end{array}$ & $\begin{array}{l}\text { Pelatihan perhusanjaringan pemseanan } \\
\text { melatui intersot (ow-ines) }\end{array}$ \\
\hline 4 & $\begin{array}{l}\text { Minimaya pengetahuan orieatasi pasar } \\
\text { (baik orientasi Konsumen mapus } \\
\text { crientasi pesaing) serta tidak mampu } \\
\text { mengidentiflasi kebuthlan konaumen } \\
\text { dan bagrimasa strategi menghadapi } \\
\text { posaingas }\end{array}$ & 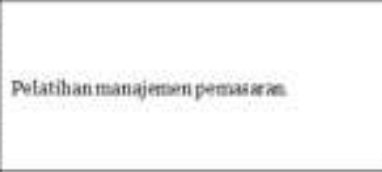 \\
\hline 5 & Rendahnya onzet pemasaran & Peningkatan davasaing \\
\hline
\end{tabular}

Penetapan prioritas ini dijustifikasi bersama antara mitra dengan tim pengusul melalui beberapa kali pertemuan dan observasi secara langsung. Berdasarkan tabel prioritas di atas, dan mengacu pada analisis situasi produsen maka telah diadakan pelbagai kegiatan untuk meningkatkan daya saing produk UMKM. Tim pengusul menentukan permasalahan dengan prioritas tinggi (No. 1 sampai dengan 5) yang telah diselesaikan dalam program ini.

\section{METODE KEGIATAN}

Metode pendekatan pelatihan dijabarkan dalam tahap-tahap sebagai berikut:

1. Tahap Penjajagan

Tim Abdimas/Pengusul yang terdiri dari Ketua (FH/Sekolah Pascasarjana), Anggota 1 (FE/ Sekolah Pascasarjana), dan anggota 2 (FTi) Universitas YARSI bekerjasama dengan Yayasan Kuntum Indonesia sebagai koordinator UMKM Kampung Wisata Binsis, dan pihak pihak terkait seperti Pemda dan Dinas Perindag, Koperasi, dan Forum UMKM Kabupaten Bogor.

2. Tahap persiapan

a) Membentuk tim yang terlibat, yakni para dosen, mahasiswa, dan mitra pengabdian kepada masayrakat

b) Menyiapkan instruktur pelatihan yang benarbenar sesuai dengan kompetensi yang dibutuhkan

c) Menyiapkan modul pelatihan sesuai dengan jenis pelatihan yang dilakukan di lokasi pengabdian.

d) Menyiapkan sarana dan prasarana pelatihan, tempat, alat dan bahan, komputer, jaringan internet, dan menyiapkan berbagai hal yang berkaitan dengan pendaftaran Merek.

3. Tahap pelaksanaan

a) Mengadakan pelatihan pelbagai pelatihan utamanya badan hukum, merek dagang dan transaksi

b) Pelatihan pemasaran produk melalui web/online dan menerapkannya.

c) Pelatihan peningkatan kompetensi manajemen pemasaran.

4. Tahap evaluasi

Evaluasi dilakukan kepada peserta pelatihan untuk mengetahui sejauh mana mereka telah memahami berbagai materi pelatihan yang diberikan oleh para narasumber, sehingga dapat dijadikan rujukan dalam melakukan umpan balik kepada khalayak sasaran.

\section{HASIL DAN PEMBAHASAN}

Keberhasilan program ini didukung oleh peranserta dosen dan mahasiswa dari Fakultas Hukum, Magister Kenotariatan, Magister Manajemen, Fakultas Ekonomi dan Teknologi Informasi serta Yayasan Kuntum Indonesia.

Jumlah UMKM di Tegal Waru sekitar 85, namun Tim Abdimas/pengusul memfokuskan pada 35 UMKM yang tergabung dalam binaan Yayasan Kuntum Indonesia. UMKM yag mengikuti need assesment berjumlah 21 .

\section{Kegiatan yang telah dilakukan adalah:}

1. Meningkatkan kesadaran pemilik UMKM akan arti pentingnya meningkatkan kualitas desain 
kemasan dan produk untuk meningkatkan prestise dan daya saing produknya.

Desain produk adalah proses perbaikan atau pengembangan mutu produk yang dirancang secara tepat untuk menghasilkan keluaran yang dapat memuaskan keinginan para pelanggan. Manfaat desain produk menurut David (2009: 251) adalah untuk meningkatkan penjualan melalui perbaikan produk atau pengembangan produk yang ada saat ini. Sedangkan Menurut Prastyowibowo (1999: 5), manfaat desain produk adalah untuk memajukan industri agar hasil industri produk tersebut dapat diterima oleh masyarakat, karena produk yang didapatkan mempunyai kualitas yang baik, harga terjangkau, desain yang menarik, mendapatkan jaminan dan sebaginya.

2. Mendampingi UMKM dalam membuat merek dagang dan memberi pengarahan dalam mengurus Merek Dagang. Pendampingan ini dipilih karena, merek (brand) merupakan bagian terpenting dari suatu produk. Merek dapat menjadi nilai tambah suatu produk. Menurut Kotler dan Keller (2009: 259), manfaat merek adalah: 1) untuk menyerderhanakan penelusuran atau penanganan suatu produk, 2) menawarkan perlidungan hukum bagi suatu perusahaan untuk fitur-fitur atau aspek uni dari suatu produk, 3) mereprestasikan bagian properti hukum yang sangat berharga, 4) sangat mempengaruhi kepercayaan konsumen, dan 5) memberikan keamanan pendapatan untuk masa depan yang lebih langgeng. Sampai saat ini produsen baru pada tahap termotivasi, namun belum ada yang secara mantap menyiapkan dengan serius berkas yang diperlukan.

3. Pelatihan pemasaran on-line dengan materi:

a. membuat web-online

b. manajemen web (pengisian konten, operasi web, pemasaran on-line praktis)

c. perawatan web

Kegiatan pelatihan pemasaran secara on-line dipilih, karena menurut Badi Uzzaman (2015), dalam bukunya yang berjudul Bisnis Pemasaran On-line, menjelaskan beberapa keuntungan bisnis on-line yaitu meliputi: 1) anpa batas waktu, 2) tanpa batas tempat, 3) efisiensi biaya operasional, 4) kemudahan dalam strategi pemasaran produk, 5) kemudaham manajemen organisasi dan produk, 6) kemudahan pengelolaan kontrol persediaan, 7) kemudahan pengelolaan sumber daya manusia, 8) Produktifitas meningkat, 9) memudahkan melakukan riset pemasaran, 10) memberikan keuntungan yang tidak terbatasdan, dan 11) kemudahan Pengawasan.

4. Pelatihan manajemen pemasaran, yang meliputi:

a. pengetahuan orientasi pasar (baik orientasi konsumen maupun orientasi pesaing)

b. pengidentifikasian kebutuhan konsumen dan

c. strategi menghadapi pesaingan

Pelatihan ini dipilih karena, menurut Stanton (2005) manajemen pemasaran merupakan seni dan ilmu untuk memilih pasar sasaran guna meraih, menghantarkan, dan mengkomunikasikan nilai pelanggan yang unggul. Manajemen pemasaran juga berusaha mengatur tingkat, waktu, dan susunan dari permintaan yang ada, agar dapat membantu organisasi mencapai sasaran dengan cara dan mendapatkan, menjaga, dan menumbuhkan pelanggan melalui penciptaan, pemberian dan pengkomukasian nilai pelanggan yang unggul.

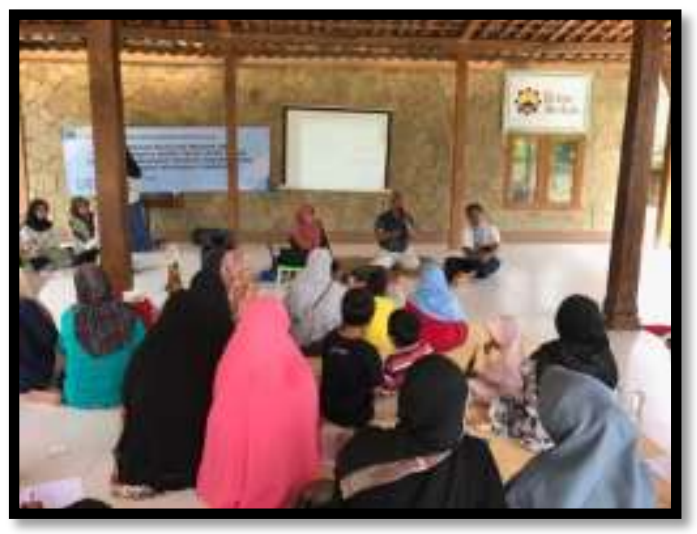

Gambar 1. Kegiatan pelatihan merek dan marketing

Jadi pada program ini kami telah melakukan:

a) Pelatihan strategi marketing, badan hukum dan pendampingan merek namun belum ada yang tergerak untuk mendaftarkan.

b) pembuatan web e commerce dan memfasisitasi serta menyewakan server selama 1 tahun. Sampai Mei tahun 2019.

c) Mendaftarkan (maksudnya mencatatkan hak cipta) video kegiatan pengabdian kepada masyarakat ini ke Ditjen KI KemenkumHAM RI. Video kegiatan juga telah diupload di https://youtu.be/yxnvtxEQZlg

d) Model pemberdayaan

e) Assesment dalam bentuk kuesioner yang analisisnya kami tampilkan sebagai berikut. 


\section{Pemahaman tentang merek dan indikasi geografis}

Berdasarkan hasil pengambilan data di lapangan dapat dipahami bahwa, pemahaman pelaku UMKM tentang merek dan indikasi geografis ratarata mendapat skor 2,3 dalam arti mereka masih kurang paham. Jumlah pelaku UMKM yang menjawab sangat tidak paham sebanyak 1 orang, menjawab tidak paham sebanyak 13 orang, menjawab cukup paham sebanyak 3 orang, menjawab paham sebanyak 2 orang, dan menjawab sangat paham sebanyak 1 orang. Untuk lebih jelasnya dapat dilihat tabel berikut.

Tabel 1. Pemahaman tentang merek dan indikasi geografis

\begin{tabular}{|l|c|c|}
\hline Deskripsi & Frekwensi & $\%$ \\
\hline Sangat kurang paham & 2 & 9,5 \\
\hline Kurang paham & 13 & 61,9 \\
\hline Cukup Paham & 3 & 14,3 \\
\hline Paham & 2 & 9,5 \\
\hline Sangat Paham & 1 & 4,8 \\
\hline Jumlah & 21 & 100 \\
\hline
\end{tabular}

Sumber: Hasil analisis data 2018

\section{Pemahaman tentang perbedaan merek dan indikasi geografis}

Berdasarkan hasil pengambilan data di lapangan dapat dipahami bahwa, pemahaman pelaku UMKM tentang perbedaan merek dan indikasi geografis rata-rata mendapat skor 2,1 dalam arti masih kurang paham. Jumlah pelaku UMKM yang menjawab sangat tidak paham sebanyak 6 orang, menjawab tidak paham sebanyak 8 orang, menjawab cukup paham sebanyak 4 orang, dan menjawab paham sebanyak 3 orang, sedangkan yang menjawab sangat paham tidak ada seorang pun. Untuk lebih jelasnya dapat dilihat tabel berikut.

Tabel 2. Pemahaman tentang perbedaan merek dan indikasi geografis

\begin{tabular}{|l|r|r|}
\hline Deskripsi & Frekwensi & \multicolumn{1}{c|}{$\%$} \\
\hline Sangat kurang paham & 6 & 28,6 \\
\hline Kurang paham & 8 & 38,1 \\
\hline Cukup Paham & 4 & 19,0 \\
\hline Paham & 3 & 14,3 \\
\hline Jumlah & 21 & 100 \\
\hline
\end{tabular}

Sumber: Hasil analisis data 2018

\section{Pemahaman tentang manajemen dan strategi pemasaran untuk branding produk}

Berdasarkan hasil pengambilan data di lapangan dapat diketahui bahwa, pemahaman pelaku UMKM tentang manajemen dan strategi pemasaran untuk branding produk rata-rata mendapat skor 2,4 dalam arti masih kurang paham. Jumlah pelaku UMKM yang menjawab sangat tidak paham sebanyak 3 orang, menjawab tidak paham sebanyak 10 orang, menjawab cukup paham sebanyak 5 orang, menjawab paham sebanyak 2 orang, dan menjawab sangat paham sebanyak 1 orang. Untuk lebih jelasnya dapat dilihat tabel berikut.

Tabel 3. Pemahaman tentang manajemen dan strategi pemasaran untuk branding produk

\begin{tabular}{|l|c|c|}
\hline Deskripsi & Frekwensi & $\%$ \\
\hline $\begin{array}{l}\text { Sangat kurang } \\
\text { paham }\end{array}$ & 3 & 14,3 \\
\hline Kurang paham & 10 & 47,6 \\
\hline Cukup Paham & 5 & 23,8 \\
\hline Paham & 2 & 9,5 \\
\hline Sangat Paham & 1 & 4,8 \\
\hline Jumlah & 21 & 100 \\
\hline
\end{tabular}

Sumber: Hasil analisis data 2018

Pemahaman tentang peraturan perundangan terkait ijin edar dan SIUP

Berdasarkan hasil pengambilan data di lapangan dapat diketahui bahwa, pemahaman pelaku UMKM tentang peraturan perundangan terkait ijin edar dan SIUP rata-rata mendapat skor 2,2 dalam arti masih kurang paham. Jumlah pelaku UMKM yang menjawab sangat tidak paham sebanyak 5 orang, menjawab tidak paham sebanyak 10 orang, menjawab cukup paham sebanyak 2 orang, dan menjawab paham sebanyak 4 orang, sedangkan yang menjawab sangat paham tidak ada seorang pun. Untuk lebih jelasnya dapat dilihat tabel berikut.

Tabel 4. Pemahaman tentang peraturan perundangan terkait ijin edar dan SIUP

\begin{tabular}{|l|c|c|}
\hline Deskripsi & Frekwensi & $\%$ \\
\hline $\begin{array}{l}\text { Sangat kurang } \\
\text { paham }\end{array}$ & 5 & 23,8 \\
\hline Kurang paham & 10 & 47,6 \\
\hline Cukup Paham & 2 & 9,5 \\
\hline Paham & 4 & 19,0 \\
\hline Jumlah & 21 & 100 \\
\hline
\end{tabular}

Sumber: Hasil analisis data 2018 


\section{Pemahaman tentang pentingnyas status badan usaha dan badan hukum}

Berdasarkan hasil pengambilan data di lapangan dapat diketahui bahwa, pemahaman pelaku UMKM tentang pentingnyas status badan usaha dan badan hukum rata-rata mendapat skor 2,5 dalam arti masih kurang paham. Jumlah pelaku UMKM yang menjawab sangat tidak paham sebanyak 6 orang, menjawab tidak paham sebanyak 3 orang, menjawab cukup paham sebanyak 8 orang, menjawab paham sebanyak 3 orang, dan menjawab sangat paham sebanyak 1 orang. Untuk lebih jelasnya dapat dilihat tabel berikut.

Tabel 5. Pemahaman tentang pentingnyas status badan usaha dan bdan hukum

\begin{tabular}{|l|c|c|}
\hline Deskripsi & Frekwensi & $\%$ \\
\hline Sangat kurang paham & 6 & 28,6 \\
\hline Kurang paham & 3 & 14,3 \\
\hline Cukup Paham & 8 & 38,1 \\
\hline Paham & 3 & 14,3 \\
\hline Sangat Paham & 1 & 4,8 \\
\hline Jumlah & 21 & 100 \\
\hline
\end{tabular}

Sumber: Hasil analisis data 2018

\section{Pemahaman tentang pentingnya halal}

Berdasarkan hasil pengambilan data dapat diketahui bahwa, pemahaman pelaku UMKM tentang pentingnya halal rata-rata mendapat skor 3,0 dalam arti sudah paham. Jumlah pelaku UMKM yang menjawab sangat tidak paham sebanyak 6 orang, menjawab cukup paham sebanyak 5 orang, menjawab paham sebanyak 7 orang, dan menjawab sangat paham sebanyak 3 orang. Untuk lebih jelasnya dapat dilihat tabel berikut.

Tabel 6. Pemahaman tentang pentingnya halal

\begin{tabular}{|l|c|c|}
\hline Deskripsi & Frekwensi & $\%$ \\
\hline Sangat kurang paham & 6 & 28,6 \\
\hline Kurang paham & 5 & 23,8 \\
\hline Cukup Paham & 7 & 33,3 \\
\hline Paham & 3 & 14,3 \\
\hline Jumlah & 21 & 100 \\
\hline
\end{tabular}

Sumber: Hasil analisis data 2018

\section{Pemahaman tentang pentingnya kualitas produk dan reputasi}

Berdasarkan hasil pengambilan data dapat diketahui bahwa, pemahaman pelaku UMKM tentang pentingnya kualitas produk dan reputasi rata-rata mendapat skor 2,6 dalam arti sudah paham.
Jumlah pelaku UMKM yang menjawab sangat tidak paham sebanyak 7 orang, menjawab tidak paham sebanyak 2 orang, menjawab cukup paham sebanyak 5 orang, menjawab paham sebanyak 5 orang, dan menjawab sangat paham sebanyak 2 orang. Untuk lebih jelasnya dapat dilihat tabel berikut.

Tabel 7.Pemahaman tentang pentingnya kualitas produk dan reputasi

\begin{tabular}{|l|c|c|}
\hline Deskripsi & Frekwensi & $\%$ \\
\hline $\begin{array}{l}\text { Sangat kurang } \\
\text { paham }\end{array}$ & 7 & 33,3 \\
\hline Kurang paham & 2 & 9,5 \\
\hline Cukup Paham & 5 & 23,8 \\
\hline Paham & 5 & 23,8 \\
\hline Sangat Paham & 2 & 9,5 \\
\hline Jumlah & 21 & 100 \\
\hline
\end{tabular}

Sumber: Hasil analisis data 2018

\section{Pemahaman tentang pentingnya desain}

Berdasarkan hasil pengambilan data diketahui bahwa, pemahaman pelaku UMKM tentang pentingnya desain rata-rata mendapat skor 2,8 dalam arti sudah paham. Jumlah pelaku UMKM yang menjawab sangat tidak paham sebanyak 4 orang, menjawab tidak paham sebanyak 5 orang, menjawab cukup paham sebanyak 4 orang, menjawab paham sebanyak 7 orang, dan menjawab sangat paham sebanyak 1 orang. Untuk lebih jelasnya dapat dilihat tabel berikut.

Tabel 8. Pemahaman tentang pentingnya desain

\begin{tabular}{|l|c|c|}
\hline Deskripsi & Frekwensi & $\%$ \\
\hline Sangat kurang paham & 4 & 19,0 \\
\hline Kurang paham & 5 & 23,8 \\
\hline Cukup Paham & 4 & 19,0 \\
\hline Paham & 7 & 33,3 \\
\hline Sangat Paham & 1 & 4,8 \\
\hline Total & 21 & 100 \\
\hline
\end{tabular}

Sumber: Hasil analisis data 2018

\section{Pemahaman tentang informasi dan transaksi elektronik (ITE) dan e-commerce}

Berdasarkan hasil pengambilan data diketahui bahwa pemahaman pelaku UMKM tentang tentang informasi dan transaksi elektronik (ITE) dan $e$ commerce rata-rata mendapat skor 2,2 dalam arti masih kurang paham. Jumlah pelaku UMKM yang menjawab sangat tidak paham sebanyak 5 orang, 
menjawab tidak paham sebanyak 10 orang, menjawab cukup paham sebanyak 3 orang, menjawab paham sebanyak 2 orang, dan menjawab sangat paham sebanyak 1 orang. Untuk lebih jelasnya dapat dilihat tabel berikut.

Tabel 9. Pemahaman tentang informasi dan transaksi elektronik (ITE) dan $e$-commerce

\begin{tabular}{|l|c|c|}
\hline Deskripsi & Frekwensi & $\%$ \\
\hline Sangat kurang paham & 5 & 23,8 \\
\hline Kurang paham & 10 & 47,6 \\
\hline Cukup Paham & 3 & 14,3 \\
\hline Paham & 2 & 9,5 \\
\hline Sangat Paham & 1 & 4,8 \\
\hline Total & 21 & 100 \\
\hline
\end{tabular}

Sumber: Hasil analisis data 2018

Dalam wawancara di Tegalwaru selama kegiatan pelatihan berlangsung Yayasan Kuntum Indonesia dan mitra (Tatik dan Rara) menyatakan bahwa web Tegal Waru sudah dibuat, e commerce belum ada, transaksi online belum dilakukan dengan baik, sebagian kecil dari mereka memanfaatkan media sosial pribadi, dan mereka memerlukan link kerjasama berbagai pihak untuk membantu. Demikian pula mereka belum tergerak untuk mendaftarkan merek, karena yang penting proiduknya lancar, laku dan survive

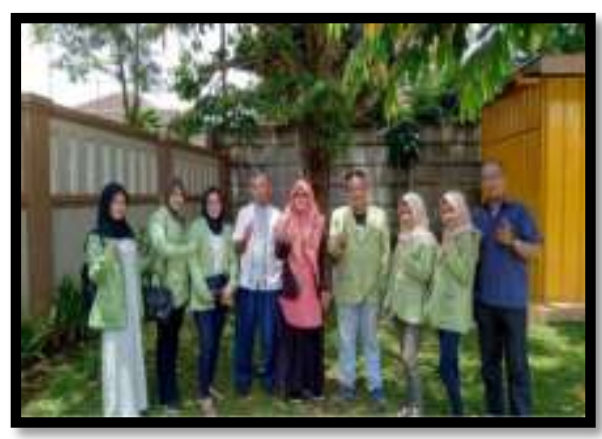

Gambar 2. Keterlibatan mahasiswa dalam pelbagai pelatihan

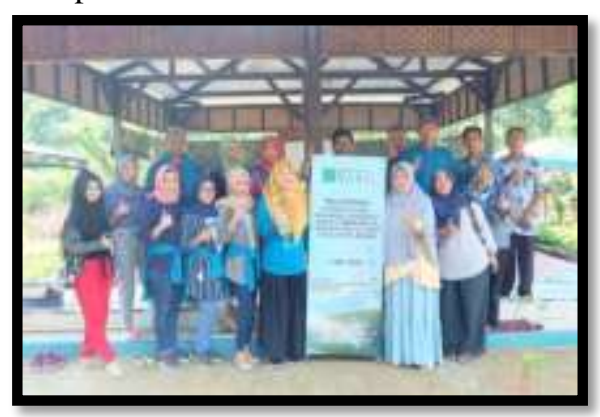

Gambar 3. Pelatihan dan serah terima e commerce system
Berikut model yang dihasilkan melalui need assesment dan wawancara langsung pada saat pelatihan.

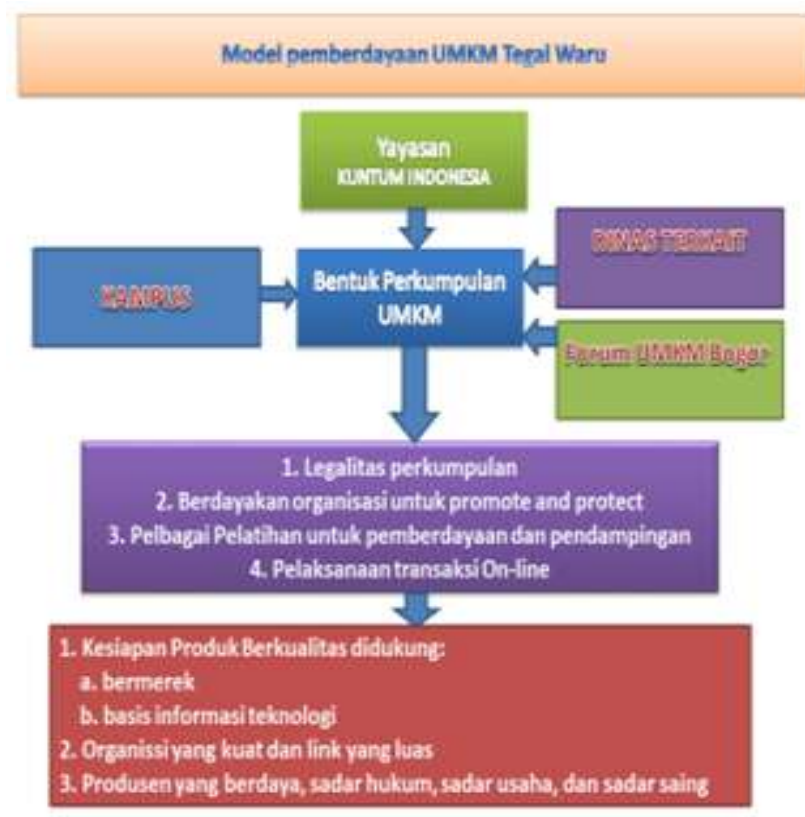

Gambar 4. Model Pemberdayaan UMKM Tegal Waru

Deskripsi Model:

1. UMKM Tegal Waru selama ini dibina oleh Yayasan Kuntum Indonesia dan belum memiliki organisasi/perkumpulan produsen, sehingga perlu dibantu untuk membuatkan legalitas usaha dalam bentuk perkumpulan. Namun terdapat kendala, bahwa produsen belum seia sekata sehingga perlu diberikan pemahaman yang mendalam dan penyamaan persepsi demi kepentingan bersama

2. Kampus (YARSI) dan Forum UMKM Bogor dan link terkait selayaknya turun tangan membantu mengatasi permasalahan

3. Pendekatan partisipatif seharusnya diterapkan untuk lebih membangkitkan motivasi, sehingga pemberdayaan pun dapat berhasil. Pelbagai pelatihan terkait produk dan manajemen serta pelindungan hukumnya sangat perlu dilakukan

4. Model pemberdayaan diterapkan dengan kerjasama pelbagai pihak, partisipasi aktif produsen itu sendiri, sehingga terwujud produk berkualitas, didukung pelindungan merek dagang, dan support kuat dari peran organisasi/perkumpulan produsen yang siap bersaing dan survive. 
Tim Abdimas juga mengadakan Focus Group Discussion (FGD) 4 September 2018 sehubungan dengan kendala pada produsen, baik belum adanya yang termotivasi mendaftarkan merek dagang, maupun terbentuknya perkumpulan secara spesifik yang mewadahi aspirasi produsen UMKM Tegal Waru. FGD dihadiri oleh para akademisi, UMKM Tegal Waru dan beberapa UMKM asal daerah lain, Ikatan Notaris Indonesia (INI) dan Ditjen Kekayaan Intelektual.

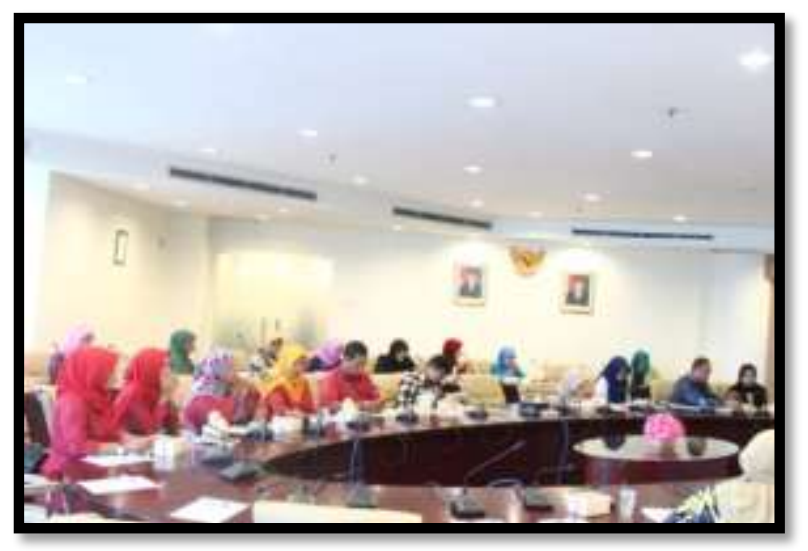

Gambar 5. FGD 4 September 2018

Berdasarkan FGD 4 September 2018, mitra berharap bantuan dari kampus tidak terhenti dan sosialisasi merek dari pemerintah lebih ditingkatkan. Ikatan Notaris Indonesia (Notaris Rita Diana Syarifah) menyatakan bahwa saat ini terdapat kerjasama antara INI dan Berkraf, yang memayungi segala urusan ijin operasional produk dan legalitas badan usaha, bahkan dibantu sampai pendaftaran merek. Demikian pula DitjekemenkumHAM RI (Ahmad Rifadi) menyatakan bahwa akan memperhatikan kepentingan UMKM dan aspirasi tersebut. Ahmad Rifadi juga menunjukkan tata cara meng search proses pendaftaran merek di DJKI, namun mitra juga mengeluhkan bahwa tidak semua produsen paham teknologi, serta keterbatasan pemanfaatan internet dan kepemilikan handphone yang hanya sekedar sarana komunikasi saja saat ini.

\section{KESIMPULAN}

1. Produsen Kampung Wisata Bisnis Tegalwaru perlu diberdayakan dari segala hal, baik status badan usaha, keberlanjutan produksi, dan membrandingnya. Meskipun Tim Abdimas telah menyumbangkan $e$ commerce dan menyewakan server 1 tahun, E commerce belum dilakukan dengan baik, sebagian kecil dari mereka belum siap dan memanfaatkan media sosial pribadi

2. Model pemberdayaan perlu diterapkan dengan link kerjasama berbagai pihak untuk membantu, mengingat produsen belum tergerak untuk mendaftarkan merek dagang, karena yang penting laku dan survive.

\section{REFERENSI}

David, Fred R. 2009, Manajemen Strategis. Jakarta: Salemba Empat. Diunduh dari epository.widyatama.ac.id/xmlui/bitstream/ha ndle/123456789 tanggal 7 Mei 2017

Kotler, Philip, dan Kevin Lane Keller. 2009. Manajemen Pemasaran Jilid 1, edisi Ketiga Belas, Terjemahan Bob Sabran. Jakarta: Penerbit. Erlangga. Diunduh dari repository.usu.ac.id/bitstream/123456789/298 86/2/Reference.pdf tanggal 7 Mei 2017

Prasetyowibowo, Bagas. 1999. Desain produk Industri, Bandung: Yayasan Depalan Sepuluh. Diunduh dari eprints.ums.ac.id/28908/7/ DAFTAR_PUSTAKA.pd tanggal 7 Mei 2017

Purwaningsih, Endang. 2015 Hukum Bisnis, Bogor: Ghalia

Stanton, William J. 1994. Fundamental of Marketing, $10^{\text {th }}$. Ed. Tokyo: Mc-Graw Hill Kogakusha. Diunduh Dari lib.ui.ac.id/file? file $=$ digital/123591 TANGGAL 7 Mei 2017

Uzzaman, Badi (2015), Bisnis Pemasaran On-line diunduh dari http://www.kembar.pro/2015/08/ apa-keun, ungan - melakukan - pemasaran secara-online.html tanggal 7 Mei 2017. 